\title{
UNION PEACETIME RESTRAINTS IN COLLECTIVE BARGAINING*
}

\author{
Chardes 0. Gregory $\dagger$
}

$\mathrm{I}$

7 HIS is a discussion of some of the activities and objectives of labor unions which have troubled many disinterested persons.

1 As such it centers around federal labor policy and touches on local views only occasionally. This, of course, is natural inasmuch as American industry on the whole has come to serve national markets and draws on the whole country for its raw materials. But the force of this observation should appear shortly.

Since this discussion is largely concerned with union restrictions on free competition of various sorts-a concern which is closely tied up with the Sherman Act-it is possible to kill two birds with one stone by describing the development of organized labor's most sweeping restraint of competition in national markets and at the same time indicating what the prevailing policy of the Supreme Court is in administering the Sherman Act. For some such background is essential to an understanding of Mr. Arnold's program of union control. ${ }^{x}$

While the immediate aim of a union may be the achievement of material advantages for its members in particular units of a nation-wide industry, its long run aim must be to retain already achieved gains. This implies a program of nationally affiliated locals governed in accordance with a common set of standards. Presumably the achievement of wage increases and of a shorter work day and week with no reduction of takehome pay means an increase in the operating costs of the unit in which these gains are won. If so, these increased costs will be reflected in the price of the product. Now, if we may also assume that the operating cost of a unionized shop is higher than that of an unorganized shop-an assumption not always, but generally, true - then we may safely conclude that the union-made product competes with the non-union product at a disadvantage in national consumption markets. By national markets are

* This article is the substance of a paper written for publication at the annual convention of the American Economic Association, in Washington, D.C., on January 4, I943.

$\dagger$ Professor of Law, University of Chicago.

× For a brief summary of this program, see Arnold, The Bottlenecks of Business c. $x$, especially at $249-53$ (1940). 
meant sales and purchases in a given place of goods supplied from points outside of the state in which such transactions occur.

It seems fairly clear that this competition between union and non-union goods has provided organized labor with its keenest organizational incentive and has given rise to the unions' major economic problem-the elimination from national markets of cheaper non-union competition. This is what Judge Andrews of New York's highest court meant when he said in I927, "Economic organization today is not based on the single shop. Unions believe that wages may be increased, collective bargaining maintained only if union conditions prevail, not in some single factory but generally." " Perhaps the unions themselves put the matter more concisely when they state the need for the universal closed shop throughout a given industry as against the single closed shop in that industry. Here it might be observed parenthetically that since the National Labor Relations Act was adopted, the emphasis on the closed union shop has lessened considerably from the economic point of view, because a union enjoying the support of a majority of the employees in a given plant is the exclusive bargaining agency for all of the employees in the appropriate unit designated and can set standards common to all. Nevertheless, of course, we all know that unions still shout for the closed shop as a device to retain majority, support from year to year, to avoid in future elections the attritional undermining effects during any given year of the employment of non-union labor in an open shop as a consequence of normal labor turnover.

But to return to the union desire to eliminate non-union competition with union products by extending organization throughout a given industry, the absorption of the United Mine Workers in this problem for so many years is a conspicuous example of what is meant. In their annual conventions year after year they discussed and voted action upon the demands of unionized operators that competing non-union mines would have to be organized or else they, the unionized mines, would either have to dispense with established union standards or shut down. ${ }^{3}$ It was this sort of pressure, as well as the natural desire for more membership and consequent power, which ultimately resulted in so-called "stranger" organizational proceedings, of which more will be said later. In any event, it probably gave rise to the impulse of the United Mine Workers to create a sort of limited universal price control over national coal markets, in connection with which the Supreme Court announced one of its earliest policy

\footnotetext{
2 Exchange Bakery \& Restaurant, Inc. v. Rifkin, 245 N.Y. 260, I57 N.E. I30 (I927).

3 See Hitchman Coal Co. v. Mitchell, 245 U.S. 229 (Igr7).
} 
viewpoints concerning organized labor and restraints on free competition in national markets. ${ }^{4}$

The Coronado strike, ${ }^{5}$ not entirely a stranger proceeding but a direct exertion of pressure with outside interest nevertheless aimed at procuring a closed union shop, succeeded in closing down the mine and, by stopping production, kept its output from entering interstate commerce. This, of course, was a restraint on commerce and was assailed as such by the mine operator under the Sherman Act. But the Court could not condemn this restraint as a violation under the Act without at the same time declaring illegal by implication all successful strikes for any purpose in units of industry supplying national markets. Such an extreme position the Court could not take as a matter of practical politics, let alone considerations of civil rights and common law. For social opinion, as well as the courts in the country, had long since accepted as proper the strike for immediate objectives such as wage and hour conditions; and several of our state supreme courts had openly approved as lawful the strike for the closed union shop. To conclude in the teeth of such social, legal, and political developments that just because a given unit of industry shipped its products to buyers in other states, a strike preventing such continued shipments through stoppage of production was therefore unlawful under the Sherman Act, while the same kind of strike at a plant selling its product locally was perfectly lawful for all purposes, would be to invite certain political disaster and to disgust the thinking people throughout the land. Although it would have been perfectly proper for the Court to have gone to this length by a literal application of certain provisions in the Act, it seems certain that by so doing the Court would thereby have brought about either immediate repeal of the Act or clearly expressed legislative removal of the unions entirely from its application. As it was, the Court probably decided the issue wisely; but its reasoning was feeble and evasive, mainly that the restraint was "indirect" and that, after all, production was only a local function. ${ }^{6}$

It is somewhat amusing to see the Court crawling in this way, particularly when it had previously with such confidence declared unlawful under the Act the Danbury Hatters ${ }^{7}$ secondary consumption boycott, with which the AFL throttled the hat factory, and the boycott of the ma-

4 United Mine Workers v. Coronado Coal Co. (First Coronado Case), 259 U.S.'344 (rg22). 5 Ibid.; Coronado Coal Co. v. United Mine Workers (Second Coronado Case), 268 U.S. 295 (1925).

${ }^{6}$ The Court cited Hammer v. Dagenhart, 247 U.S. $25 \mathrm{I}$ (rgr8), as a compelling precedent.

7 Loewe v. Lawler, 208 U.S. 274 (Ig08). 
chinists' union in the Duplex case. ${ }^{8}$ But these cases, the Court said, were different. Actually, however, the only difference between them and the strike was the type of coercive technique employed by the union to reduce the company to a state of non-production. Of course, the practical difference was that the Court did not mind cracking down on a secondary boycott, which all so-called "right-minded" people regarded as unlawful, anyway, and could refer to it as a direct restraint with a clear conscience in spite of the fact that it was regarded as quite lawful by several state courts.

But the Court's desire either to "get" the union in the Coronado case or to spike the organizational strike in national industries must have prompted it to devise a method for using the Sherman Act to the desired end. For the Court threw out a dictum to the effect that evidence indicating that the strike had been intended by the union to keep the mine's nonunion coal from competing with union-mined coal in a national market would be sufficient to prove a violation of the Act. But it had to be evidence of subjective intent. This seems clearly to have been a clear-cut case of a verbum sapienti. The Chief Justice must have realized that the point of most organizational strikes was, by unionizing the product of the struck shop, to eliminate its competition in its non-union character with the already unionized product in the same market. And he probably knew that astute counsel could dig up this evidence in most organizational strike cases. Anyway, counsel did just that in the Coronado case by procuring a disgruntled union participant in the strategy of the strike to squeal; ${ }^{9}$ and by the alchemy of legal theory the same strike which had formerly been held not a violation of the Act suddenly became one.

Although few, if any, of our leading jurists or economists realized it at the time, the Chief Justice had in his, hint to counsel anticipated what was twenty years after to become the rationale of the Act as it applied to organized labor. In the $A$ pex case ${ }^{\mathrm{xo}}$ last year Mr. Justice Stone declared in no uncertain terms that strange misconceptions of the application of the Sherman Act to labor had long existed. Most of this, he said, was confusion between such restraints on or interferences with commerce as would give Congress the power to act at all under the commerce clause and, on the other hand, such restraints or interferences which Congress in a particular statute had intended to forbid. For instance, many people thought and still think that because the Court has held that Congress has

8 Duplex Printing Press Co. v. Deering, 254 U.S. 443 (rg2r).

${ }^{9}$ Coronado Coal Co. v. United Mine Workers, 268 U.S. 295 (I925).

ro Apex Hosiery Co. v. Leader, 310 U.S. 469 (I940). 
the power in the Wagner Act ${ }^{\mathrm{xx}}$ to protect commerce from strikes by outlawing unfair employer practices, it should therefore hold that all such strikes are likewise illegal restraints under the Sherman Act. Now Mr. Justice Stone seems correct in saying that this in itself is poor reasoning. All the Wagner Act cases really mean is that Congress always has the power under the commerce clause to relieve commerce from the burden of strikes if it wishes to do so. It obviously did wish to do so in the Wagner Act, although not by declaring such strikes unlawful but rather by outlawing conditions which it thought gave rise to them. Did it wish to do that in the Sherman Act? Certainly that is a matter of doubt. It said nothing about strikes or other labor activities in that Act. Really, it said nothing much of anything except to evince in a general sort of way a desire to protect commerce from the dangers of combinations, trusts, and monopolies. And if such benevolent yearnings could, through analogy to old common-law restraints of trade, be construed as a general effort to protect consumers and goods markets from the competition-killing restraints of combinations, then Mr. Justice Stone seems to have been justified in concluding that Congress had meant in the Act only to protect markets from the restrictive controls which combinations interested in controlling the markets as such were wont to place on them. All the plaintiff had shown in the $A$ pex case was that the union had by its sit-down strike or seizure closed down the shop and had forcibly prevented certain goods from being sent out to plaintiff's customers-coercion practiced by a defendant not interested in cornering the market on silk stockings but interested only in compelling a manufacturer, through economic embarrassment, to go union.

Mr. Justice Stone clearly stated existing national policy toward union activities, as voiced by Congress in the Sherman Act or elsewhere, then, to be only one of preventing their control of goods or commodities markets, labor and services being clearly excepted from inclusion as a commodity: Thus, he declared, any union activity directed toward control of the labor market is under existing federal law perfectly acceptable; and the fact that such activities interfere with the shipment of goods in interstate commerce or with the production of goods destined for such shipments cannot be regarded as unlawful so long as they are carried on to coerce an employer through economic embarrassment into dealing with a particular union. But, Mr. Justice Stone continued, the boycott restraints on commerce are nevertheless violations, even though they are clearly organizational efforts, if actually they substantially affect the

${ }^{{ }^{2}} 49$ Stat. 449 (I935), 29 U.S.C.A. \& ${ }_{5 \mathrm{I}}$ (1942). 
market in the product of the employer involved. What he means by "substantially" nobody knows, since he said that the Danbury Hatters, Duplex, and Bedford cases $^{\mathrm{I2}}$ were still good law. And then came the most questionable part of his opinion, in view of his thesis that only market controls as such were to be considered unlawful. He declared that universal unionization of an industry, even if it were proved to be an undertaking to eliminate the competition between union-made and non-unionmade products, is permissible because such an aim is such an integral part of the American union movement that to deny it, even if it is an obvious market control of goods, would be virtually to deny unionism. But we have accepted unionism as a part of our economic life; therefore, we have accepted its most fundamental economic objectives. Of course, he remarked that this universal organization was but another aspect of the monopolization of or control over labor or services as contrasted to goods or commodities and could be explained entirely as such. Yet it is submitted as an instance of a wholesale goods market control that has the sanction of the present Court in spite of the interpretation by the same Court of existing legislation as protection of national markets from controls over price, supply, and discriminations among would-be purchasers and sellers.

Subsequently, of course, Mr. Justice Frankfurter, with three other members of the present Court concurring in his opinion, went far beyond Mr. Justice Stone's position and declared that no union activity fairly described either in Section 20 of the Clayton Act or in Section 4 of the Norris-LaGuardia Act, ${ }^{13}$ apparently regardless of its object or of any inherent vice thought to be peculiar to such conduct, was lawful for all purposes under federal law. ${ }^{\mathrm{I}}$ This meant that these four justices believe Congress not to have forbidden any union conduct not involving fraud, violence, or defamation, as far as one can tell from reading the sections referred to; and the upshot of the Hutcheson case leaves the unions a free hand to achieve any end they wish as long as they resort only to purely economic pressures, regardless of their effect on commerce or on any other part of our economy.

\section{II}

This review of the cases may have seemed tedious; but it appears futile to discuss possible controls over union activities without some apprecia-

I2 Bedford Cut Stone Co. v. Journeymen Stone Cutters' Ass'n, 274 U.S. 37 (1927); Duplex Printing Press Co. v. Deering, 254 U.S. 443 (rg2r); Loewe v. Lawler, 208 U.S. 274 (Igo8).

${ }^{13} 47$ Stat. 70 (r933), 29 U.S.C.A. § ror (I942).

${ }_{4}$ United States v. Hutcheson, 3r2 U.S. 2 Ig $_{9}$ (I94I). 
tion of the nature of the existing controls. And it is rash to assume that present policy is understood clearly by all of the profession. At any rate, it must be fairly clear now that Congress has done virtually nothing to prevent the abuses which worry Mr. Arnold. For the Court has told us that the Sherman Act is very definitely not the Thurman Act!

$\mathrm{Mr}$. Arnold deprecates at least five labor union practices which he believes too unwholesome for the continued passive sanction of Congress. These are, briefly, (I) practices designed to prevent the use of cheaper material, improved equipment, and more efficient methods, (2) practices designed to compel the hiring of useless and unnecessary labor, (3) practices designed to enforce systems of graft and extortion, (4) practices designed to enforce illegally fixed prices, and (5) practices designed to destroy an established and legitimate system of collective bargaining, by which he means to refer to the so-called jurisdictional dispute in both of its possible meanings. ${ }^{15}$ Now it is extremely difficult not to accept $\mathrm{Mr}$. Arnold's program. He, in turn, has gone far to meet organized labor halfway. He has always accepted the late Mr. Justice Brandeis' position that nationally organized unions should be allowed a very wide latitude as a matter of civil rights in promoting organization and in collective bargaining. And Mr. Arnold, in his desire to distinguish clearly between organizational and bargaining activities on the one hand and what he would term illegitimate efforts toward gain on the other, would probably agree with Mr. Justice Brandeis that the old boycott precedents referred to above should be overruled. Indeed, it is likely that he would even accept a good deal that Mr. Justice Stone said in his Apex opinion. But in his attempts to safeguard the interests of American consumers, all he had to play with was the Sherman Act as he found it; and now it transpires that he needs the help of Congress itself, which can no longer hide behind the affected good-will of the general propositions in the Sherman Act but must come forward and deal specifically with isolated sore spots on the body politic.

The question has been asked whether the consuming public cannot be protected against the impositions of labor unions through the fact that in collective bargaining between unions and employers there exists an inherent antagonism of interests between the parties to such bargaining, so that the employer, in serving his own interests, beats down the union in such a way that the public interest is automatically served. It would, indeed, be a rash conjecture to assert that there is nothing in this hope; but it seems safe to say that there is not much in it. One should not be thought

ז5 Arnold, The Bottlenecks of Business 25I-52 (I940). 
anti-union, or, indeed, anti-social, when he urges that none of us can afford to entertain any illusions about the self-conceived interests of either the unions, or of the employers with whom they deal. An objective conception of unionism is that it is a collective endeavor to procure advantage for its constituents by a group which is not accepting its definition of selfinterest from anyone, economists or others, but is spelling out the definition itself. Now economists may differ from the union conception of selfinterest; and in the long run they may prove to be quite correct, if we ever have any way of telling. But in the social system now existing here, the unions are entitled to their own notions. Hence, given the freedom of economic action which our present laws guarantee the unions, why should we suppose that they will not take advantage of them in bargaining collectively with employers? After all, we must not forget that collective bargaining is not always consummated around the conference table, for a good deal of it is articulated through the strike, the boycott, and the picket line-all permissible gambits except during the war. From this one may conclude that the unions have a pretty good answer to the argument that the conflict of interests between the parties to collective bargaining will protect the consumer.

Moreover, in view of this state of affairs, it seems idle to assume that the average employer will push his supposed interests far enough ever to justify a suspicion that he might thus protect the public interest. Employers are probably far more interested in continued operations on a profit-making basis and are not unaware of the advantages of purchasing peace by making concessions, particularly if they can at the same time insure that their competitors will be made subject to the same concessions they themselves have granted. Naturally, an employer is extremely anxious to remain able to market his product profitably. But it seems equally patent that the union with which he is dealing is no less anxious that this should continue to be so. Employers as a rule are most adaptable, and they are inclined to accept conditions and try to make the best of them as long as they do not have sufficient political or economic solidarity among themselves to change these conditions. There are other factors, also, which lead to the belief that employers may be prone to capitulate to the demands of unions, as long as they know that their competitors will all be in the same boat. Thus an increasingly large amount of the purchasing power in this country is getting into the hands of organized wage-earners, and producers can less afford to associate their products with an antiunion bias. ${ }^{16}$ Then the products of many employers are not intended for

${ }^{16}$ This may have been a factor in Henry Ford's sudden decision to contract with the UAW-CIO. 
direct ultimate consumption but are supplied as parts to other employers whose organized employees may at any time refuse to work on them in the interests of total unionism if these parts are not union-made or if their producers are having trouble with some union.

This alleged consumer protection through employer-union antinomy, then, seems a very thin reed on which to balance the public interest. It might be otherwise if employers were allowed freely to organize together and to conduct a knock-down and drag-out fight with the unions. At least, under such circumstances, we might expect a more traditional articulation of employer interests as employers really see them. But such a spectacle would probably have disastrous immediate effects on consumer interests; and it is doubtful whether the public would really like such a process of protection. If past experience of employer interests' ganging up on unions is any index, it is doubtful whether any real solace could be expected from such tactics, anyway.

The conviction seems reasonable, then, that the only feasible hope for the elimination of undesirable union practices harmful to consumers' interests is, first, for the proponents of such a program to take a not too broad view of what in unionism is objectionable and, second, for them to awaken sufficient political interest in the public to have Congress pass legislation specifically addressed to particular objectionable practices or to any practices curtailing particular desirable economic processes. It seems essential that this reform program be not too sweeping, for it is hard to conceive of a political undertaking so large as virtually to throw the baby out with the bath, assuming unionism to be the baby. For instance, a good deal of organized labor's self-help procedure like strikes, boycotts, etc., as well as some of their institutions like the closed shop, single and universal, already seem to be confirmed national institutions which it is now too late culturally to prohibit. After all, Mr. Justice Stone was substantially correct when he said that acceptance of labor unionism at all implies its acceptance as it is, including the institutions and most of the practices which make it what it is.

With respect to outlawing interferences with the use of cheaper material, improved equipment, and more efficient methods, ${ }^{17}$ as well as compelling the use of unnecessary labor, ${ }^{18}$ the American judiciary has already shown signs -in our state courts, at least ${ }^{\mathrm{x}}$ - of retracting its former

${ }^{27}$ For example, United States v. Goedde, 40 F. Supp. 523 (IIl. I94I).

${ }^{28}$ For example, United States v. Carrozzo, 37 F. Supp. Igr (IIl. I940), aff'd sub nom. United States v. Int'I Hod Carriers' and Common Laborers' District Council, $3^{\text {I } 3}$ U.S. 539 (I94I).

${ }^{29}$ For example, Opera on Tour, Inc. v. Weber, 285 N.Y. 348,34 N.E. (2d) 349 (I94I), cert. den. on grounds that no federal question was involved, 3 I $_{4}$ U.S. 6 I $_{5}$ (I94I). 
laissez faire notions about freedom of union self-help activity, although the federal courts under the Sherman Act and Anti-racketeering Act ${ }^{20}$ have staunchly refrained from interfering with the gainful pursuits of certain unions, carried on at the expense of society through the loss of progressive production methods. ${ }^{2 x}$ The rationale of the New York court in denying the musicians' and stagehands' unions the privilege of striking to prevent the use of canned music in a travelling opera enterprise employing only live singers but not live musicians is, first, to deny the existence of a labor dispute in order to take the case out of the state anti-injunction law and, then, to assume that any union opposition to mechanical progress of service to mankind is, in the nature of things, unlawful..$^{22}$ It is, of course, hard to find fault with the court's instinct in this case; but it is harder to condone its ruthless disregard of the law as the legislature has written it. ${ }^{23}$ And this is particularly true of all who deplore such sheer judicial legislation by the courts and who still believe that only the legislature in a truly democratic state can unmake the law which it has already made under open political sanctions. Thus, we may hate strikes or boycotts directed against painting machines, portable concrete mixers, oneoperator busses and trucks, prefabricated houses, cheaper and better building materials, movie organs, recorded music on the radio, and a host of other new products and devices which would make living cheaper and more comfortable for consumers. But we must remember that established unions have vested interests in the continuation of older methods which require more labor and thus provide more jobs. At least they think they have; and they are privileged to act on their convictions under our present laws unless the public through open political action takes steps to pass legislation specifically directed against continuance of practices intended to defeat progressive methods and to retain high labor costs. How such practices can be prevented by collective bargaining alone is hard to imagine. It is true that prohibitory legislation alone will not be the complete answer, since technological displacement of workers is a social problem to deal with which a well coordinated displacement unemployment compensation, a re-training program, and an intelligent re-employment

${ }^{20} 48$ Stat. 979 ( 1934 ), I8 U.S.C. $\$ \$ 4202-e$ (I94I).

${ }^{2 x}$ Cases cited in notes ${ }_{5} 5$ and $x 6$ supra illustrate the federal attitude toward such activities under the Sherman Act, while the most indicative case arising under the Anti-racketeering Act is United States v. Local 807, 315 U.S. 52I (1942).

${ }^{22}$ Opera on Tour, Inc. v. Weber, 285 N.Y. 348,34 N.E. (2d) 349 (r94I), cert. den. on grounds that no federal question was involved, 3I4 U.S. 6I5 (I94I).

${ }^{23}$ The New York Anti-injunction Act has substantially the same provisions as does the Norris-LaGuardia Act, N.Y. Civ. Prac. Ann. (Gilbert-Bliss, Supp. I94r) $\$ 876-a$. 
service are required. We may agree that employees alone should not get the complete advantage of more efficient operations as they think they will when they object to the lowering of piece rates, for instance, when more efficient production techniques make possible the manufacture of more units per hour. Certainly we may agree that employers should not get the full benefit of such technological changes-a result not likely to happen while competition remains alive, except insofar as patents or devices making such changes possible may keep prices up. At the same time it may be difficult to agree with the Wisconsin legislator ${ }^{24}$ who proposed in a bill that half of the savings effected by all labor-savings devices should be put into a fund to pay unemployment compensation to those displaced by the technological changes in question. Since the public as consumers should get the entire benefit of such developments, it is obviously up to the public to place a premium on these changes by assuming the burden of temporary maladjustments which they cause in employment. And a program of this sort obviously cannot be worked out by collective bargaining since it must have a uniform over-all effect such as can be handled only through regulatory legislation and public funds.

Little space need be devoted here to Mr. Arnold's plea for sanctions against union graft and extortion. ${ }^{25}$ Happily, it is not very widespread. But when it occurs, it is usually in spite of collective bargaining, and it is made possible only through the exercise of the power which our liberal laws have enabled the unions to create. This plea calls for rather straightforward regulatory legislation very analogous to that already passed to control the abuses of corporate power, perhaps not unlike the Securities Act and the Securities and Exchange Act. Such a program would encourage the filing of individual claims for redress by businessmen adversely affected and by individual workmen, union members, or others who had suffered from unfair entrance exactions or from some other form of internal maladministration of a particular union.

Quite a different problem is presented by union attempts to enforce illegally fixed prices-Mr. Arnold's fourth complaint. Citing the Brims case, ${ }^{26} \mathrm{Mr}$. Justice Frankfurter asserted as dictum in the Hutcheson case that this is a practice for which the unions may be called to account under the Sherman Act as it now stands. ${ }^{27}$ For it is not easy, under our present law, to have illegal fixing of prices by union action alone. And when a

\footnotetext{
24 Landis, Cases on Labor Law 35 In. I (1934).

25 For example, the indictment brought in United States v. Local 807, 3 I5 U.S. 52 (I942).

${ }^{26}$ United States v. Brims, 272 U.S. 549 (1926).

27 United States v. Hutcheson, 312 U.S. 219, 232 (I94I).
} 
union connives with one or more manufacturers or business houses to maintain prices, the Court through Mr. Justice Frankfurter has said that this is going too far. Yet this assurance is not comforting, in light of the Court's general remarks in the Hutcheson case. For if a union puts its price-fixing sanctions into effect by means of the types of peaceful, economic pressures described as non-enjoinable in the Norris-LaGuardia Act and in Section 20 of the Clayton Act, I for one find it hard to believe that such conduct will be held illegal for any purpose and under any circumstances unless the Court overrules its stand in the Hutcheson case. And yet all must agree that if employers cannot combine to maintain prices, certainly the unions should not be allowed to do it either independently or for the employers as they may virtually do indirectly through fixing labor standards throughout an entire industry. Again, however, we are confronted with the full implications of the universal closed union shop throughout an industry as a device to protect hard-won labor standards by maintaining at a uniform level the price of the commodity in question in national markets.' But this is a feature of unionism which Mr. Justice Stone has assured everyone is not unlawful but is, rather, an integral factor of legitimate unionism, apparently to remain free from interference as long as we have labor organizations for any purpose. ${ }^{28}$ Hence, about the only instances of price control which can be controlled or outlawed are those achieved through connivance with employers by the process of collective bargaining.

When Mr. Arnold insists upon a measure to prevent union attempts to destroy an established and legitimate system of collective bargaining, he is referring to those union power grabs which are commonly known as jurisdictional disputes. ${ }^{29}$ Concerning the exact nature of this type of activity there is, unfortunately, considerable confusion. The original jurisdictional strike was a combat between two craft unions, both of which were usually affiliated with the same national federation, the contest being to determine which union was going to perform certain specific work. For instance, ${ }^{30}$ suppose that carpenters had always hung doors which, of course, had always been made of wood, while the metal workers had al-, ways installed metal fixtures. On a particular building project the plans call for metal doors, and the general contractor or his sub-contractor hires carpenters to install these doors. The metal workers thereupon strike

${ }^{28}$ Apèx Hosiery Co. v. Leader, 3ro U.S. 469, 503-4 (I940).

${ }^{29}$ In the argument which the government presented in the Hutcheson case, the presence of a jurisdictional dispute was treated as a highly significant factor.

${ }^{30}$ Central Metal Products Corp. v. O'Brien, 278 Fed. 827 (D.C. Ohio I922). 
other work they are doing until this work is given to them. And if it is given to them, the carpenters strike. Shocking wastes have occurred, particularly in the building trades, because of such jurisdictional disputes. The AFL attempted to reconcile these differences within its own organization by creating a Board of Jurisdictional Awards; ${ }^{3 x}$ but this board's decisions were never very effective, apparently because they were influenced by internal federation politics. The stronger union seemed to win the awards too consistently. In the meantime, huge building projects were forced to a standstill while the general contractor and owner did not care which set of workmen did the job as long as it was done. Such interference with building may not seem a matter of federal concern; but its control is within the scope of Congressional power because of the effect such delays have on the interstate movement of building materials. The analogy to the exercise of power in the Wagner Act is perfect.

Strictly speaking, the plight of the general contractor in such cases is not much different from that which confronts him when he introduces nonunion labor on a certain job in a building project where union labor is performing other jobs. A strike called by the local building trades council, comprising all of the unions normally involved in construction, to compel the hiring of only union men for all of the work is, however, accepted with more or less complacence nowadays, because the employer's way out of the strike is so clear. All he has to do is to hire union men. To many, of course, this sort of union pressure is shocking enough; but it is a practice which is recognized as lawful in most of our courts today, at least in peacetime. Now the difference between a jurisdictional strike in a project where all employees are union men and a strike by union men where some nonunion men are employed may well be in legal or other theory only one of degree. It may be said of each strike that it is but the collective exercise of the civil right of workingmen to refuse employment except under conditions congenial to their interests. But it seems plain that when such differences of degree result in terrific economic loss unavoidable by the employer, then it becomes a matter of such public interest that the alleged civil right of unions to conduct jurisdictional strikes can and should be curtailed.

It has been said by persons present in the Supreme Court during the argument of the Eutcheson case that Mr. Justice Frankfurter made some interesting observations on this type of jurisdictional dispute, one of which was involved in that case. He is said to have remarked that jurisdictional disputes, unfortunate as they may be, have yet their advantages to society

${ }^{3 \times}$ Landis and Manoff, Cases on Labor Law IoI-IO5 (I942). 
in that their very wastefulness and harm to the unions themselves will speed the day of industrial, as compared to craft, organization. This implies that Mr. Justice Frankfurter believes industrial union organization to be preferable to craft organization as a matter of general values. Why he believes this, after all, is fairly apparent, since collective bargaining in a large industrial unit comprising several kinds of work is essentially more simple when carried on through one union than when it is conducted with a half dozen or more. It may be interesting to observe in passing that the building trades craft unions have already achieved a substantial solidarity of a sort which usually accompanies industrial organization. Thus, although the craft delineation remains, the building trades council has enabled the united front of the employees against the employer for matters of general union interest and for mutual aid and assistance, leaving them separate for the purposes of particular craft interests and for inter-craft conflicts. But whether or not it is wise to encourage the abolition of craft unions in order thus to obviate the old-fashioned jurisdictional dispute is a matter which our ultimate arbiters of policy must decide. Many of us remain convinced that if the road to this possible solution is unrestricted privilege to pull jurisdictional strikes, the method of cure may have disastrous effects on the body politic and economic.

The other type of jurisdictional dispute - that of which we hear more about these days-is really the expression of inter-union conflict. For instance, examples of this are the conflicts between the AFL and the CIO carpenters' and woodworkers' unions to organize the employees in units of industry which their respective organizations are set up to control. ${ }^{32}$ Other instances are the conflicts between unions affiliated with either of the larger national systems and relatively local independent unions, the current struggle between moving picture operators' unions in New York being a graphic example. ${ }^{33}$ These conflicts are a matter of grave public concern for several reasons. Thus, where one of the unions has members in two operations so that the first operation manufactures a commodity used in the second operation, while the other union has established itself only in the first operation, the more comprehensive union has, and uses, a beautiful opportunity to boycott the product of the other union by refusing to work on it. As where the CIO has organized units producing plywood on which AFL members employed in enterprises

\footnotetext{
32 United States v. United Brotherhood of Carpenters and Joiners of America, filed with memorandum opinion, sustaining on authority of the Hutcheson case, demurrers to the indictment, 4 C.C.H. Lab. Cas. I5I,II8 (D.C. Ill. I94I), aff'd $3 I_{3}$ U.S. 539 (I94I).

${ }^{33}$ Loew's, Inc. v. Basson, 46 F. Supp. 66 (N.Y. 1942), noted to Univ. Chi. L. Rev. 226 (r943).
} 
using plywood refuse to work as long as it is made by CIO men; ${ }^{34}$ and where AFL moving picture film workers refuse to work on film which their employer rents to theatres which do not employ AFL projectors but, rather, employ projectors whose union covers only the projection operation. ${ }^{35}$ Such boycotts create real interferences with the interstate movement of commodities; and while they are fundamentally the collective exercise of civil rights to work or not work except under agreeable conditions, yet they create disturbances of commerce which would certainly justify suitable Congressional action, whatever that might be.

But a better reason for concern over this internecine strife lies in the ridiculous plight in which it often puts employers. Many of these get beyond caring whether one union or another represents their men, as long as production can continue..$^{36}$ For these employers cannot any longer decide with which union they will deal. Under the Wagner Act, that is a matter for the employees alone to decide. Still, the Wagner Act does not say that unions may not undertake to influence the choice of the employees in any particular plant; and outside unions, with impunity, have even tied up plants where the employers had bargained and contracted with the unions certified to them by the National Labor Relations Board as the duly-chosen representatives of the majority of their employees. Now this sort of coercion may well be the collective exercise of civil rights to picket or to refuse work not agreeable to the men in question if the device used is the boycott, and it may well be actively carried on in the "allowable area of economic conflict," to quote from the opinion of a judge in one of the most aggravating of cases involving a similar situation. ${ }^{37}$ But the definition of civil rights and of legitimate economic conflict might well be made in light of the common interests of all and not merely to further the interests of those groups claiming these extraordinary privileges.

These practices which have been recounted in this paper should be subjected to any controls specifically aimed at them in accordance with open, democratic, political processes and should not be sheltered behind the cloak of broad and general constitutional protection. At the same time, in the opinion of the Supreme Court, Congress has not up to the present,

34 United States v. United Brotherhood of Carpenters and Joiners of America, fled with memorandum opinion, sustaining on authority of the Hutcheson case, demurrers to the indictment, 4 C.C.H. Lab. Cas. I5I,II8 (D.C. Ill. I94I), aff'd 313 U.S. 539 (I94I).

${ }^{35}$ Although the union which was directly involved was solely a projectionists' union, it had been in a position to ask AFL unions engaged in other film operations to join them in a strike.

${ }^{36}$ Stillwell Theatre, Inc. v. Kaplan, 259 N.Y. 405 , 182 N.E. 63 (I932); NLRB v. Star Publishing Co., 97 F. (2d) 465 (C.C.A. 9th 1938 ).

${ }^{37}$ Pound, C. J., in Stillwell Theatre, Inc. v. Kaplan, 259 N.Y. 405, I82 N.E. 63 (I932). 
either in the Sherman Act or in any other law, done anything about correcting these practices. It would seem unfortunate for any Congress to abolish the outstanding labor legislation of the past ten years. But Congress can certainly improve such legislation if it makes a careful and thoughtful effort to prohibit the continuation of practices such as those recounted here. For it seems abundantly clear that as long as the large nationally-federated unions retain the privilege of exercising such powers, they cannot be expected to abandon such privilege in their collective bargaining with employers. In short, protection of the consuming public through collective bargaining seems most unlikely because of the inherent opposition of interests between the parties to collective agreements-the employer and the union. 